\title{
The Household Bankruptcy Decision
}

\author{
By Scott Fay, Erik Hurst, and Michelle J. White*
}

Personal bankruptcy filings have risen from 0.3 percent of households per year in 1984 to around 1.35 percent in 1998 and 1999, transforming bankruptcy from a rare occurrence to a routine event. Lenders lost about $\$ 39$ billion in 1998 due to personal bankruptcy filings. ${ }^{1}$ But economists have little understanding of why households file for bankruptcy or why filings have increased so rapidly. Until very recently, studying the household bankruptcy decision was very difficult, because no household-level data set existed that included information on bankruptcy filings. In this paper, we use new data from the Panel Study of Income Dynamics, which includes information on bankruptcy filings, to estimate a model of households' bankruptcy decisions.

We find support for the strategic model of bankruptcy, which predicts that households are more likely to file when their financial benefit from filing is higher. Our model predicts that an increase of $\$ 1,000$ in households' financial benefit from bankruptcy would result in a 7-percent increase in the number of bankruptcy filings. Our model also predicts that if the $1997 \mathrm{Na}$ tional Bankruptcy Review Commission's proposed changes in bankruptcy exemption levels were implemented, there would be a 16-percent increase in the number of bankruptcy filings each year. But if the $\$ 100,000$ cap on homestead exemptions recently passed by the U.S.

\footnotetext{
* Fay: Warrington College of Business Administration, University of Florida; Hurst: Graduate School of Business, University of Chicago; White: Department of Economics, University of California, San Diego, and NBER. We are grateful to Orley Ashenfelter, John Bound, Charlie Brown, Paul Courant, Austan Goolsbee, Jim Hines, Joe Lupton, Ariel Pakes, Gary Solon, Nicholas Souleles, Frank Stafford, Elizabeth Warren, and an anonymous referee for helpful comments, and to Citibank and the National Science Foundation, under Grant No. SBR 96-17712, for financial support. Earlier versions of this paper were presented at Harvard University, the Wharton School, the University of Chicago, UCLA, and the American Law and Economics Association Conference.

${ }^{1}$ This figure is based on unsecured debt per bankruptcy filing of $\$ 28,000$ (John M. Barron and Michael Staten, 1998).
}

Senate were adopted, our model predicts that there would be only a negligible effect on the number of filings. We find little support for the nonstrategic model of bankruptcy which predicts that households file when adverse events occur which reduce their ability to repay. Finally, controlling for state and time fixed effects, our model shows that households are more likely to file for bankruptcy if they live in districts with higher aggregate filing rates.

\section{U.S. Personal Bankruptcy Law}

The United States has two different personal bankruptcy procedures-Chapter 7 and Chapter 13-and debtors have the right to choose between them.

Chapter 7.--Under Chapter 7, unsecured debts such as credit card debt, installment loans, medical bills, and damage claims are discharged. Debtors are not obliged to use any of their future earnings to repay their debt, but they are obliged to turn over all of their assets above a fixed exemption level to the bankruptcy trustee. The trustee liquidates the nonexempt assets and uses the proceeds to repay creditors. Although bankruptcy is a matter of federal law and the rules are uniform across the United States, Congress gave the states the right to adopt their own bankruptcy exemptions. Most states have separate exemptions for equity in the debtor's principle residence (the "homestead exemption") and for several types of personal property. In general, states' nonhomestead exemptions are low, but their homestead exemptions vary widely, from a few thousand dollars to unlimited in nine states. ${ }^{2}$ If debtors' assets are less than the exemption levels in their states, then they are not obliged to repay anything to creditors.

\footnotetext{
${ }^{2}$ The average value of all nonhomestead exemptions in 1995 was $\$ 5,000$. The average homestead exemption in 1995 for states that do not have unlimited homestead exemptions was $\$ 25,000$. Most states also exempt clothing, furniture, and household goods.
} 
Households' financial benefit from filing for bankruptcy under Chapter 7 is therefore the value of debt discharged and their financial cost is the value of nonexempt assets, if any, that they must give up. Households' net financial benefit from filing for bankruptcy is the difference. Households that file for bankruptcy must also pay bankruptcy court filing fees and lawyers' fees. They also face possible nonpecuniary costs, including the cost of acquiring information about the bankruptcy process, higher future borrowing costs, and the cost of bankruptcy stigma.

Chapter 13.-Chapter 13 bankruptcy is intended for debtors who earn regular incomes. Under it, debtors do not give up any assets in bankruptcy, but they must propose a plan to repay a portion of their debts from future income, usually over three to five years. The plan goes into effect as long as the bankruptcy judge accepts it, i.e., creditors do not have the right to block repayment plans.

Because debtors have the right to choose between Chapters 7 and 13, they have a financial incentive to choose Chapter 7 whenever their assets are less than their state's exemption, since doing so allows them to avoid repaying their debts completely. ${ }^{3}$ Even when households file under Chapter 13, they are obliged to use future earnings to repay debt only to the extent that they would be obliged to use nonexempt assets to repay debt under Chapter 7 . For example, debtors who have $\$ 5,000$ in nonexempt assets are obliged to repay only the equivalent of $\$ 5,000$ from future earnings in a repayment plan under Chapter 13. Debtors who have no nonexempt assets sometimes file under Chapter 13 , but propose to repay only token amounts. Bankruptcy judges vary in their willingness to accept these plans. ${ }^{4}$

\footnotetext{
${ }^{3}$ Debtors may shift assets from nonexempt to exempt categories before filing or use other strategies to reduce their nonexempt assets before filing. Debtors may also default on their debt but not file for bankruptcy, since creditors do not always attempt to collect. See White (1998a) for discussion.

${ }^{4}$ About 70 percent of bankruptcy filings occur under Chapter 7. Congress has attempted to make Chapter 13 more attractive to debtors by allowing some types of debts-including some student loans and debts incurred by fraud - to be discharged under Chapter 13, but not under Chapter 7. Debtors are also allowed to file under Chapter 13 as often as every six months, while they cannot file under
}

\section{Literature Review}

Attempts to study the bankruptcy filing decision have been hampered by the lack of household-level data on bankruptcy filings. In an early study, White (1987) regressed the aggregate bankruptcy filing rate by county on the bankruptcy exemption level for the relevant state and other variables. She found that the bankruptcy filing rate was positively and significantly related to the exemption level. ${ }^{5}$ Ian Domowitz and Robert L. Sartain (1999) got around the lack of household-level data on bankruptcy filings by combining two data sources: a sample of households that filed for bankruptcy under Chapter 7 in the early 1980's and a representative sample of U.S. households which includes detailed financial information (the 1983 Survey of Consumer Finances). They found that households with more credit card debt were more likely to file for bankruptcy. David Gross and Nicholas Souleles (2002) used a data set of individual credit card accounts to explain account holders' bankruptcy decisions. Their main explanatory variable is lenders' rating of individual account holders' riskiness and their main finding is that, after controlling for the increase in the average borrower's riskiness, the probability of default rose significantly between 1995 and 1997. They interpret this result as evidence that the level of bankruptcy stigma has fallen. Neither the Domowitz and Sartain nor the Gross and Souleles papers tested whether households' decisions to file for bankruptcy are related to their financial benefit from filing, which is a central goal of this study. ${ }^{6}$

Chapter 7 more often than once every six years. Chapter 13 is also attractive to debtors who own homes and are in arrears on mortgage payments, because it delays foreclosure. In 1984, Congress adopted a provision intended to prevent high-income debtors from filing under Chapter 7 , but later court decisions and lack of enforcement made it ineffective. See Karen Gross (1986), Wayne R. Wells et al. (1991), and White (1998b) for discussions of this provision and the relationship between Chapters 7 and 13 .

${ }^{5}$ Frank H. Buckley and Margaret F. Brinig (1998) did a similar study using state rather than county bankruptcy filing rates, for the years 1980 to 1991. They found a negative relationship between state aggregate filing rates and the exemption level.

${ }^{6}$ For theoretical models of the bankruptcy decision, see Samuel A. Rea, Jr. (1984) and Ronald A. Dye (1986). Buckley (1994) discusses explanations for the pro-debtor tilt of U.S. bankruptcy policy. Reint Gropp et al. (1997) 
There is also a sociologically oriented literature on the bankruptcy filing decision. Teresa A. Sullivan et al. (1989) examined the characteristics of a sample of households that filed for bankruptcy during the early 1980's. Based on descriptive evidence, they argued that households file for bankruptcy when unexpected adverse events occur which reduce their ability to repay their debts. Sullivan et al. also argue that households do not take financial benefit into account in making their bankruptcy decisions. We test the adverse events hypothesis in our empirical work. $^{7}$

Finally, evidence from several sources suggests that the administration and practice of bankruptcy law vary across bankruptcy districts, which may cause incentives to file for bankruptcy to vary across districts. Jean Braucher (1993) interviewed bankruptcy lawyers in four bankruptcy districts and found that they often discourage debtors who have less than a minimum amount of dischargeable debt from filing for bankruptcy, but the minimum amount varies across districts. Braucher also notes that bankruptcy trustees in each district set standard legal fees for Chapter 7 and Chapter 13 bankruptcy filings. Because these fees vary widely across districts, lawyers' incentives to specialize in bankruptcy cases also vary across districts. Both Braucher and Sullivan et al. (1989) have noted that there are large variations across bankruptcy districts in the proportion of filings that occur under Chapter 13, which they attribute to judges or lawyers in particular districts encouraging debtors to file under Chapter 13. But pressure to file under Chapter 13 could make filing for bankruptcy either more or less attractive overall, depending on whether bankruptcy judges in the district are willing to accept token repayment plans under Chapter 13. In our empirical work, we test whether the individual households' decisions to file for bankruptcy are influenced by the number of bankruptcy filings in their districts.

investigate the effect of variations in bankruptcy exemptions on supply and demand for consumer credit.

${ }^{7}$ A Washington Post (February 18, 2000) editorial arguing against changing current bankruptcy law suggests that this is a commonly held view: "Most bankruptcies are triggered by misfortune, not irresponsibility: by illness, a job loss, a broken marriage. America should remain the home of second chances."

\section{Data and Specification}

In 1996, the Panel Study of Income Dynamics (PSID) asked respondents whether they had ever filed for bankruptcy and, if so, in what year(s). Our data set is a combined crosssection, time-series sample of PSID households in the years 1984-1995. We run probit regressions explaining whether household $i$ filed for bankruptcy in year $t .^{8}$

The independent variables test three hypotheses: whether households are more likely to file for bankruptcy as their net financial benefit from filing increases, whether (controlling for financial benefit) they are more likely to file for bankruptcy when adverse events occur, and whether households' bankruptcy decisions are influenced by average bankruptcy filing rates in the localities where they live.

\section{A. Financial Benefit}

Consider first the hypothesis that households are more likely to file for bankruptcy as their net financial benefit from filing increases. As discussed above, household $i$ 's net financial benefit from filing for Chapter 7 bankruptcy in year $t$ is:

$$
\text { FinBen }_{i t}=\max \left[D_{i t}-\max \left[W_{i t}-E_{i t}, 0\right], 0\right]
$$

where $D_{i t}$ is the value of household $i$ 's unsecured debt that would be discharged in bankruptcy in year $t, W_{i t}$ is household $i$ 's wealth in

\footnotetext{
${ }^{8}$ In order for particular households to be included in our sample, they must have answered all of the PSID questionnaires for the years 1992-1995. Households that are in the sample for 1992-1995 are also included for any of the additional years 1984-1991 for which data are available. We used a balanced panel for the years 1992-1995 because the PSID data sets for 1993-1996 are only available in "early release" form and no household weights are included. We therefore used 1992 household weights for all of the 1993-1995 observations. The "early release" data sets also omit households' state of residence. As a result, we are forced to assume that households observed in 1993-1995 still live in the same state where they lived in 1992 . We used the confidential PSID geocodes to assign households to their counties of residence in each year of the sample (up to 1992). This allows us to assign households to bankruptcy districts and also to use county-level data for the unemployment rate. Because we use the PSID weights, our sample is representative of the general population.
} 
year $t$ net of secured debts such as mortgages and car loans, and $E_{i t}$ is the bankruptcy exemption in household $i$ 's state of residence in year $t$. When household $i$ files for bankruptcy, debts of $D_{i t}$ are discharged, but the household must give up assets of value $W_{i t}-E_{i t}$ if its wealth $W_{i t}$ exceeds the exemption level $E_{i t}$. FinBen $n_{i t}$ must be nonnegative, since households would not file for bankruptcy if their nonexempt assets exceeded the amount of debt discharged. Although equation (1) gives the financial benefit of filing under Chapter 7, it also applies to filing under Chapter 13, because-as discussed above-households have a choice between the two procedures and their financial benefit from filing under Chapter 13 is closely related to their financial benefit from filing under Chapter 7 .

To calculate financial benefit, we obtained exemption levels by state from 1984-1995 for equity in owner-occupied homes, equity in vehicles, and personal property applicable to financial assets, plus the wild card exemption (which can be applied to any asset). The bankruptcy exemption variable $E_{i t}$ is assumed to equal the sum of these exemptions if the household owns its own home or the sum of the vehicle, personal property, and wild card exemptions if the household rents. Since most states allow married couples who file for bankruptcy to take higher exemptions, we also adjust the exemption levels by the appropriate amount if the household contains a married couple. If the state's homestead exemption is unlimited and the household owns its own home, we assume that the value of the homestead exemption equals the value of the household's home. ${ }^{9}$ Sixteen states also allow their residents to choose between the state's exemption and a uniform federal bankruptcy exemption. For residents of these states, we use the larger of the state or the federal exemption. ${ }^{10}$

The other variables needed to calculate net

\footnotetext{
${ }^{9}$ This assumes that households take advantage of the various bankruptcy exemptions by converting assets from nonexempt to exempt categories where possible.

${ }^{10}$ In the 1978 Bankruptcy Code, Congress adopted a uniform federal bankruptcy exemption, but permitted states to opt out of the federal exemption by adopting their own exemptions. All states had done so by 1983 , but about one-third of the states allow their residents to choose between the state and the federal exemptions. Since the early 1980 's, the pattern has been that states change their exemption levels only rarely-mainly to correct nominal exemp-
}

financial benefit, $D_{i t}$ and $W_{i t}$, are taken from the PSID. The PSID asks questions concerning the amount of unsecured debt and the value of nonhousing wealth only as part of the wealth supplements, which were conducted in 1984, 1989, and 1994, but it asks the value of housing equity every year. We use 1984, 1989, and 1994 data on unsecured debt to construct $D_{i t}$ for each of the years 1984-1988, 1989-1993, and 1994-1995, respectively. Household $i$ 's wealth in year $t, W_{i t}$, equals the value of housing equity in year $t$ plus the value of nonhousing assets from the most recent wealth survey prior to year $t$. The fact that data on unsecured debt and nonhousing assets are only available in five-year increments means that our measure of financial benefit is subject to measurement error. $^{11}$

We include both financial benefit and financial benefit squared as regressors in our model of the bankruptcy filing decision in order to test for potential nonlinearities in the effect of financial benefit on the bankruptcy decision.

\section{B. Adverse Events}

The nonstrategic view of bankruptcy is that households do not plan in advance for bankruptcy and do not respond to financial gain in deciding whether to file. Instead, they file in response to unanticipated adverse events which reduce their ability to repay their debts. We would like to test the nonstrategic model of bankruptcy against the strategic model just discussed. A strict interpretation of the nonstrategic model implies that income should be negatively and significantly related to the probability of filing for bankruptcy, because income measures ability to repay debt. But financial benefit should not be significantly related to the probability of filing, because households' financial benefit from filing depends only on their wealth and not on their incomes. Conversely, a strict interpretation of the strategic model implies

\footnotetext{
tion levels for inflation. Because of this, we treat the exemption levels as exogenous.

${ }^{11}$ See our working paper, Fay et al. (1998), for discussion of how measurement error might bias our findings of the marginal effect of changes in financial benefit on households' probability of filing for bankruptcy and a test for the effect of measurement error. We find that measurement error does not significantly affect our results.
} 
that the financial benefit variable should be positively and significantly related to the probability of filing for bankruptcy, but income should not, because income is unrelated to the financial gain from bankruptcy. Thus a regression of income and financial benefit on whether households file for bankruptcy should allow us to distinguish between the theories.

However, mismeasurement of wealth is likely to prevent us from cleanly distinguishing between the two theories. As discussed above, our measure of financial benefit relies on wealth data which is only collected at five-year increments. Since current income acts as a proxy for the change in wealth since the last time the PSID collected wealth data, a finding that income is significantly related to the probability of filing for bankruptcy could support either theory. ${ }^{12}$

In our base-case specification, we include as regressors household $i$ 's income in year $t-1$ and the reduction in household $i$ 's income between year $t-2$ and year $t-1$ if income fell, or else zero. We also estimate a version of our model that excludes the income variables, but includes direct measures of whether adverse events occurred.

\section{Local Trends}

We also test whether households' bankruptcy filing decisions are influenced by the aggregate bankruptcy filing rates in their localities in the previous year. As discussed above, there are differences in the way bankruptcy law is administered and practiced across bankruptcy districts which make filing persistently more attractive in certain districts. Because we include state fixed effects in our regressions, persistent differences between the district and the national filing rates will be captured by the state fixed effects, except to the extent that districts' filing rates differ from their states' filing rates. However, an increase in a district's filing rate may also start an information cascade which causes the trend of bankruptcy filings in the district to differ from the national trend. A survey of recent bankruptcy filers by Visa U.S.A., Inc.

\footnotetext{
${ }^{12}$ Hurst et al. (1998) show that over 35 percent of five-year wealth changes in the PSID can be explained by household income, age, education, race, and initial wealth.
}

(1997) found that half of them first heard about bankruptcy from friends or relatives. Also, respondents reported that they were very apprehensive about filing for bankruptcy beforehand, but found the actual process of filing much quicker and easier than they expected. If households live in a district with a higher bankruptcy filing rate, then they are more likely to hear firsthand about bankruptcy from friends or relatives because the latter are more likely to have filed. Their friends/relatives will probably tell them that filing for bankruptcy is quick and easy. This information will tend to make households more comfortable with the idea of bankruptcy, so that the level of bankruptcy stigma falls and individual households' probabilities of filing rise. Higher filing rates then continue the process of shifting attitudes toward a more favorable view of bankruptcy.

We test for local trends in the bankruptcy filing rate by entering the aggregate filing rate in the household's bankruptcy district the previous year. ${ }^{13}$ Because we also include state and year fixed effects in our regressions, the coefficient of the lagged aggregate bankruptcy filing rate tests whether households are more likely to file for bankruptcy if they live in districts with higher aggregate filing rates, controlling for persistent differences across states in bankruptcy filing rates and for the national trend in bankruptcy filing rates. A significant coefficient on the lagged bankruptcy filing rate in the district could reflect local differences in the level of bankruptcy stigma or local differences in the administration of bankruptcy law that make the district differ from the state, or could reflect the influence of information cascades.

\section{Other Variables}

We include a vector of demographic variables which may be related to households' decisions to file for bankruptcy. These are the age and age squared of the household head, the head's education level, family size, whether the household owns its own home, and whether the household head or spouse owns a business. The

\footnotetext{
${ }^{13}$ Bankruptcy court districts are the same as federal district court districts. There are 90 individual bankruptcy court districts, with one to four districts in each state. We are grateful to Ted Eisenberg for providing us with a program which assigns counties to federal court districts.
} 
probability of filing for bankruptcy is likely to be increasing in the head's age since age brings increasing access to credit, but eventually the effect should reverse as households accumulate wealth and demand less credit. The predicted effect of being a homeowner is ambiguous. Households that have home equity greater than the homestead exemption have an incentive not to file because they must give up their homes in bankruptcy. However homeowners who have fallen behind on their mortgage payments can benefit from filing for bankruptcy, since filing delays foreclosure. The business ownership variable is particularly of interest since those who own businesses presumably have greater variance of wealth and are less risk averse than households in general. Both of these factors tend to increase the probability of filing for bankruptcy. In addition, owners of failed businesses have a particularly strong incentive to file, because business debts are discharged in bankruptcy along with unsecured personal debts. We expect households that own businesses to be more likely to file for bankruptcy.

As an inverse proxy for legal fees in filing for bankruptcy, we include the number of lawyers per 1,000 population in household $i$ 's state of residence in year $t$. Where there are more lawyers per capita, there is likely to be more competition among lawyers and more advertising of bankruptcy by lawyers, both of which cause legal fees and the costs of becoming informed about bankruptcy to fall. The lawyers per capita variable is predicted to be positively related to the probability of filing for bankruptcy. ${ }^{14}$

We also include several state- or county-level variables: the change in average income in household $i$ 's state of residence between years $t-1$ and $t$, the standard deviation of income per capita in the state (calculated over the period 1980 to 1995 ), and the unemployment rate in household $i$ 's county of residence in year $t$.

\footnotetext{
${ }^{14}$ The bankruptcy court filing fee is uniform across the country but varies over time, so that it is captured by the year fixed effects. Another cost of filing for bankruptcy is the loss of future access to credit. We assume that this cost is proxied by household demographic characteristics and by aggregate market conditions. Because markets for mortgages and consumer credit are national, we assume that future borrowing costs do not differ across localities. (See Staten [1993] for a survey of bankrupts which showed that 73 percent were able to obtain credit within a year after their bankruptcy filings.)
}

Table 1 - The Percentage of Households that Filed FOR BANKRUPTCY BY YEAR

\begin{tabular}{ccc}
\hline \hline Year & $\begin{array}{c}\text { All U.S. households } \\
\text { (percent) }\end{array}$ & $\begin{array}{c}\text { PSID sample } \\
\text { (percent) }\end{array}$ \\
\hline 1984 & 0.33 & 0.09 \\
1985 & 0.39 & 0.34 \\
1986 & 0.51 & 0.21 \\
1987 & 0.55 & 0.10 \\
1988 & 0.60 & 0.33 \\
1989 & 0.66 & 0.37 \\
1990 & 0.77 & 0.41 \\
1991 & 0.93 & 0.31 \\
1992 & 0.94 & 0.39 \\
1993 & 0.84 & 0.33 \\
1994 & 0.80 & 0.42 \\
1995 & 0.88 & 0.41 \\
\hline
\end{tabular}

Sources: The number of U.S. nonbusiness bankruptcy filings comes from the Administrative Office of the U.S. Courts and the number of U.S. households comes from the Statistical Abstract of the United States (U.S. Department of Commerce, 1997).

These variables capture differences in macroeconomic conditions across bankruptcy districts or unobserved changes in wealth or other variables that affect the bankruptcy decision and are correlated with state or district economic activity. Finally we include state and year fixed effects. ${ }^{15}$

\section{Results}

Table 1 gives the percent of households that filed for bankruptcy each year from 1984 to 1995 for both our sample and for U.S. households overall. It should be noted that our sample contains only 254 bankruptcy filings. Over the period 1984-1995, the national bankruptcy filing rate rose from 0.33 percent to 0.88 percent, with most of the increase coming in the 1980's. While the correlation between the national bankruptcy filing rate and the PSID filing rate is 0.67 , the PSID filing rate is only about half as high as the national rate. ${ }^{16}$

\footnotetext{
${ }^{15}$ We could not include other legal variables, such as whether household $i$ 's state prohibits wage garnishment, because few states changed their garnishment rules during our period. The effects of state-level legal rules and other differences across states are captured by the state fixed effects.

${ }^{16}$ Applying the analysis of J. A. Hausman et al. (1998) to our data implies that, if the number of households who reported no bankruptcy but actually went bankrupt is small relative to the number of households that actually did not
} 
Table 2-The Percentage of Households That Would Benefit Financially FROM FILING FOR BANKRUPTCY

\begin{tabular}{lcccc}
\hline \hline Financial gain $\left(\right.$ FinBen $\left._{i t}\right)$ & 1984 & 1989 & 1994 & All years \\
\hline Greater than $\$ 0$ (percent) & 17.9 & 18.6 & 16.8 & 18.5 \\
Greater than \$2,500 (percent) & 10.6 & 8.8 & 11.8 & 10.0 \\
Greater than \$10,000 (percent) & 3.1 & 2.5 & 4.8 & 3.1 \\
Median & $-\$ 27,000$ & $-\$ 29,000$ & $-\$ 34,000$ & $-\$ 26,000$ \\
Mean & $-\$ 145,000$ & $-\$ 160,000$ & $-\$ 162,000$ & $-\$ 144,000$ \\
\hline
\end{tabular}

Notes: FinBen ${ }_{i t}$ equals the value of household $i$ 's debt that would be discharged if it filed for bankruptcy in year $t$ minus the value of household $i$ 's nonexempt assets in year $t$. FinBen $n_{i t}$ must be nonnegative. All dollar values are in 1996 dollars.

Table 2 gives information concerning the distribution of households' financial benefit from bankruptcy $\left(\right.$ FinBen $\left._{i t}\right)$ for the years in which the PSID collected wealth data $(1984,1989$, and 1994). About 18 percent of households would gain financially if they filed. About 10 percent of households would gain $\$ 2,500$ or more and therefore have a substantial incentive to file. Overall, a much larger proportion of households has a financial incentive to file for bankruptcy than actually files each year. Of the households that would not gain from filing for bankruptcy, many have no unsecured debts and no nonexempt assets. These results are similar to those found by White (1998a) in calculations using the 1992 Survey of Consumer Finance, which contains much more detailed wealth data.

Table 3 gives summary statistics.

Regression I in Table 4 gives the results of a probit regression that explains whether household $i$ filed for bankruptcy in year $t$ as a function of financial benefit, financial benefit squared, and other variables. ${ }^{17}$ The coefficient

file for bankruptcy, as it presumably is in our data, then the underreporting of bankruptcy filings will lead to a slight downward bias in our estimated coefficients.

${ }^{17}$ See Robert Moffitt (1981) and Orley Ashenfelter (1983) for discussion of the problems of estimating individual households' participation in social programs when participation is voluntary, but the program imposes an implicit tax on the earnings of those who choose to participate. However, the bankruptcy filing decision differs from the decision to participate in income maintenance programs since filing for bankruptcy under Chapter 7 does not impose a tax on debtors' future earnings. Filing for bankruptcy under Chapter 13 does impose a tax on future earnings, but the tax rate varies and is strongly influenced by debtors' option to file under Chapter 7. of FinBen ${ }_{i t}$, the net financial benefit of bankruptcy, is positive and highly statistically significant $(p<0.001){ }^{18}$ The coefficient of FinBen ${ }_{i t}^{2}$ is small and negative, but is also statistically significant $(p=0.010) .{ }^{19}$ The positive sign and statistical significance of FinBen $_{i t}$ provides strong support for the hypothesis that households respond to financial incentives in making their bankruptcy decisions. The lagged aggregate bankruptcy filing rate in the household's district is positive as predicted and statistically significant ( $p=0.023)$. We discuss the marginal effects of these variables in the next section. ${ }^{20}$

Both household income and the reduction in income are negatively related to the probability of filing for bankruptcy and statistically significant $(p<0.001$ for both). Because income and the reduction in income could be acting as proxies for unmeasured changes in wealth for the years in which the PSID did not collect

\footnotetext{
${ }^{18}$ Standard errors are corrected using the Huber/White procedure, which allows error terms for the same individual to be correlated over time.

${ }^{19}$ The negative coefficient of FinBen ${ }_{i t}^{2}$ probably results from the fact that a few households in the data set did not file for bankruptcy despite having very large positive financial benefit.

${ }^{20}$ We would have liked to take advantage of the panel aspect of our data by differencing out the individual-specific component of the bankruptcy decision. But running a discrete choice model with individual fixed or random effects can be extremely problematic (see William Greene, 1993). Gary Chamberlain (1980) suggested a method for estimating a conditional likelihood logit with individual fixed effects, in which only within-individual variation contributes to the likelihood. But because relatively few households file for bankruptcy, this method is not well suited to our data.
} 
Table 3-Variable Means for the PSID BANKRUPTCY SAMPLE

\begin{tabular}{|c|c|c|}
\hline Variable & $\begin{array}{l}\text { Mean } \\
\text { value }\end{array}$ & $\begin{array}{l}\text { Standard } \\
\text { deviation }\end{array}$ \\
\hline $\begin{array}{l}\text { Financial benefit } \\
\qquad\left(\text { FinBen }_{i t}\right)\end{array}$ & $-\$ 146,000$ & 608,000 \\
\hline $\begin{array}{l}\text { Financial benefit } \\
\quad\left(\text { if } \text { FinBen }_{i t}>0\right)\end{array}$ & $\$ 7,813$ & 27,600 \\
\hline Debts (if FinBen $_{i t}>0$ ) & $\$ 9,329$ & 31,800 \\
\hline $\begin{array}{l}\text { Nonexempt assets } \\
\quad\left(\text { if } \text { FinBen }_{i t}>0\right)\end{array}$ & $\$ 585$ & 15,000 \\
\hline Lagged bankruptcy rate & 0.02312 & 0.0138 \\
\hline Household labor income & $\$ 27,570$ & 37,100 \\
\hline Reduction in income & $-\$ 3,438$ & 15,300 \\
\hline Age of household head & 47.26 & 17.00 \\
\hline $\begin{array}{l}\text { Years of education of } \\
\text { household head }\end{array}$ & 12.27 & 4.68 \\
\hline Family size & 2.66 & 1.48 \\
\hline Own business ${ }^{\mathrm{a}}$ & 0.123 & 0.329 \\
\hline Own home ${ }^{a}$ & 0.656 & 0.475 \\
\hline Lawyers per capita & 0.286 & 0.0938 \\
\hline State income growth & 0.058 & 0.029 \\
\hline State income deviation & 4.06 & 0.956 \\
\hline $\begin{array}{l}\text { Head divorced during } \\
\text { previous year }^{\mathrm{a}}\end{array}$ & 0.034 & 0.181 \\
\hline $\begin{array}{l}\text { Unemployment during } \\
\text { previous year }^{\mathrm{a}}\end{array}$ & 0.042 & 0.202 \\
\hline $\begin{array}{l}\text { Health problems during } \\
\text { previous year }^{\text {a }}\end{array}$ & 0.071 & 0.257 \\
\hline
\end{tabular}

Notes: The lagged bankruptcy rate is the aggregate bankruptcy filing rate in household $i$ 's bankruptcy district in the previous year. The reduction in income equals the amount that household $i$ 's income fell from year $t-2$ to year $t-$ 1 , if income fell, or else zero. Lawyers per capita is the number of lawyers per capita in household $i$ 's state of residence in year $t$. State income deviation is the standard deviation of average income in household $i$ 's state of residence, calculated over the period 1980-1995.

${ }^{\mathrm{a}}$ Indicates a dummy variable (yes $=1$ ).

wealth data, these results do not allow us to distinguish between the strategic versus the nonstrategic models of the bankruptcy decision. Of the demographic variables, the age of the household head, age squared, the head's education level, and family size are all statistically significant and all have the predicted signs.

The dummy variable for whether the household owns its own home is negative and marginally significant $(p=0.080){ }^{21}$ The dummy variable for owning a business has the expected positive sign, but is not statistically significant.

\footnotetext{
${ }^{21}$ Domowitz and Sartain (1999) also found that homeowning was negatively related to the bankruptcy filing decision.
}

The number of lawyers per 1,000 population in households' state of residence-our proxy for legal costs - is negative rather than positive as predicted, but not significant. None of the macroeconomic variables that we included as additional controls were statistically significant.

Regression I imposes the restriction that the two components of FinBen ${ }_{i t}$ and FinBen Fit $^{2}$, unsecured debts that would be discharged in bankruptcy and nonexempt assets that must be given up in bankruptcy, must have coefficients of the same absolute value but opposite signs. In regression II, we relax this restriction. We therefore drop FinBen Fit $_{\text {and }}$ FinBen it $^{2}$ from the model. We replace them with debts for households that have positive financial benefit from bankruptcy, or else zero, and nonexempt assets for households that have positive financial benefit from bankruptcy, or else zero. [See equation (1).] We also include debts squared, nonexempt assets squared, and an interaction term between debts and nonexempt assets. If debts and nonexempt assets affect the bankruptcy decision equally, then the predictions are that the coefficients of debts and nonexempt assets will be equal in magnitude but opposite in sign, the coefficients of debts squared and nonexempt assets squared will be equal in magnitude and the same sign, and the coefficient of the interaction term will be twice as large and of the opposite sign as the coefficients of debts squared or nonexempt assets squared.

The results are given in regression II of Table 4 . They show that the coefficient of debts is positive as predicted and statistically significant, but the coefficient of nonexempt assets is positive-rather than negative as predictedand insignificant. We can marginally reject the null hypothesis that the two coefficients have the same value but opposite signs using a Wald test $(p=0.082)$. It should be noted that the coefficient of debts in regression II is similar to the coefficient of FinBen $_{i t}$ in regression I $\left(4.76 e^{-5}\right.$ versus $\left.5.66 e^{-5}\right)$. The coefficient of debts squared is negative and statistically significant and the coefficient of nonexempt assets squared is also negative, but not significant. We cannot reject the null hypothesis that the two coefficients are the same $(p=0.335)$. Finally, the interaction term is negative as predicted, but insignificant. We cannot reject the null hypotheses that -2 times the coefficient of the interaction term equals the coefficient of debts 
TABle 4-Results ExPlaining Whether Households File for BANKRuPtCy

\begin{tabular}{|c|c|c|c|c|c|c|}
\hline \multirow[b]{2}{*}{ Variable } & \multicolumn{2}{|c|}{ I } & \multicolumn{2}{|l|}{ II } & \multicolumn{2}{|c|}{ III } \\
\hline & Coefficient & $\begin{array}{l}\text { Standard } \\
\text { error }\end{array}$ & Coefficient & $\begin{array}{l}\text { Standard } \\
\text { error }\end{array}$ & Coefficient & $\begin{array}{l}\text { Standard } \\
\text { error }\end{array}$ \\
\hline Constant & -2.24 & 0.541 & -2.23 & 0.541 & -1.95 & 0.524 \\
\hline Financial benefit & $5.66 \times 10^{-5}$ & $1.15 \times 10^{-5}$ & - & - & $5.61 \times 10^{-5}$ & $1.14 \times 10^{-5}$ \\
\hline$(\text { Financial benefit })^{2}$ & $-1.04 \times 10^{-9}$ & $4.04 \times 10^{-10}$ & - & - & $-1.03 \times 10^{-9}$ & $4.00 \times 10^{-10}$ \\
\hline Debts (if $\mathrm{FinBen}_{i t}>0$ ) & - & - & $4.76 \times 10^{-5}$ & $1.05 \times 10^{-5}$ & - & - \\
\hline \multicolumn{7}{|l|}{ Nonexempt assets } \\
\hline$\left(\right.$ if FinBen $\left._{i t}>0\right)$ & - & - & $1.59 \times 10^{-4}$ & $1.18 \times 10^{-4}$ & - & - \\
\hline$(\text { Debts })^{2}$ & - & - & $-7.54 \times 10^{-10}$ & $3.32 \times 10^{-10}$ & - & - \\
\hline (Nonexempt assets) $^{2}$ & - & - & $-5.27 \times 10^{-9}$ & $4.67 \times 10^{-9}$ & - & - \\
\hline Interaction term & - & - & $-1.10 \times 10^{-8}$ & $1.56 \times 10^{-8}$ & - & - \\
\hline Lagged bankruptcy rate & 5.92 & 2.60 & 5.84 & 2.58 & 5.78 & 2.59 \\
\hline Household labor income & $-5.34 \times 10^{-6}$ & $1.42 \times 10^{-6}$ & $-5.42 \times 10^{-6}$ & $1.42 \times 10^{-6}$ & - & - \\
\hline Reduction in income & $-2.15 \times 10^{-6}$ & $6.00 \times 10^{-7}$ & $-2.15 \times 10^{-6}$ & $5.97 \times 10^{-7}$ & - & - \\
\hline Age of household head & 0.030 & 0.014 & 0.030 & 0.014 & 0.018 & 0.013 \\
\hline$(\mathrm{Age})^{2}$ & $-4.89 \times 10^{-4}$ & $1.55 \times 10^{-4}$ & $-4.95 \times 10^{-4}$ & $1.56 \times 10^{-4}$ & $-3.52 \times 10^{-4}$ & $1.47 \times 10^{-4}$ \\
\hline Years of education & -0.029 & 0.012 & -0.029 & 0.012 & -0.037 & 0.011 \\
\hline Family size & 0.038 & 0.017 & 0.037 & 0.017 & 0.032 & 0.017 \\
\hline Own business & 0.035 & 0.092 & 0.038 & 0.092 & 0.092 & 0.090 \\
\hline Own home & -0.131 & 0.075 & -0.125 & 0.075 & -0.192 & 0.068 \\
\hline Lawyers per capita & 0.413 & 0.804 & 0.415 & 0.808 & -0.535 & 0.797 \\
\hline County unemployment rate & -0.009 & 0.016 & -0.008 & 0.016 & -0.005 & 0.016 \\
\hline State income growth & -1.93 & 1.19 & -1.87 & 1.19 & -1.84 & 1.18 \\
\hline State income deviation & -0.128 & 0.091 & -0.130 & 0.091 & -0.134 & 0.091 \\
\hline Divorce & - & - & - & - & 0.228 & 0.129 \\
\hline Period of unemployment & - & - & - & - & 0.110 & 0.123 \\
\hline Health problems & - & - & - & - & 0.092 & 0.117 \\
\hline State fixed effects & yes & & yes & & yes & \\
\hline Year fixed effects & yes & & yes & & yes & \\
\hline
\end{tabular}

Notes: The sample size for all regressions is 55,487. All regressions use the PSID family weights. Standard errors are corrected using the Huber/White procedure, which allows error terms for the same household to be correlated over time.

squared or nonexempt assets squared ( $p=$ 0.466 and 0.439 , respectively). ${ }^{22}$ These results suggest that debts and assets play different roles in the bankruptcy decision. For households in our sample, discharge of debts is the dominant financial consideration in the decision to file for bankruptcy, while the obligation to use nonexempt assets to repay debts plays little role.

In regression III, we explore the adverse events hypothesis further by rerunning regression I, but omitting the income and reduction in income variables and introducing dummy variables for adverse events which the household experienced the previous year: health problems for the household head or spouse, spells of

\footnotetext{
22 The null hypothesis of no joint significance for debts and nonexempt assets in regression II can be rejected $(p<$ 0.001). The null hypothesis of no joint significance for debts squared, nonexempt assets squared and the interaction term can marginally be rejected $(p<0.078)$.
}

unemployment for the head or spouse (if s/he previously worked), and the household head being divorced in the previous year. ${ }^{23}$ The results show that all three of the adverse event variables have the predicted positive signs, but only the divorce variable is close to statistical significance $(p=0.077)$. These results suggest little support for the nonstrategic model of the bankruptcy decision, controlling for the level of financial benefit. The coefficients of the financial benefit variables remain the same as in regression $\mathrm{I}^{24}$

\footnotetext{
${ }^{23}$ Income and the reduction in income are omitted because they are highly correlated with all three of the adverse events variables.

${ }^{24}$ In addition to divorce reducing ability to pay, the correlation between divorce and bankruptcy may reflect the fact that divorce lawyers often counsel their clients to file for bankruptcy.
} 
TABLE 5-PREDICTIONS

\begin{tabular}{|c|c|c|c|}
\hline Variable & Hypothesized change & $\begin{array}{c}\text { Percentage point } \\
\text { marginal effect }\end{array}$ & $\begin{array}{l}\text { Percentage change } \\
\text { in the filing rate }\end{array}$ \\
\hline \multicolumn{4}{|l|}{ Regression I } \\
\hline Financial benefit & $+\$ 1,000$ & $\begin{array}{c}0.021 \\
(0.005)\end{array}$ & 7.0 \\
\hline 1997 NBRC proposal & (see text) & $\begin{array}{c}0.048 \\
(0.011)\end{array}$ & 15.9 \\
\hline $\begin{array}{l}\text { Cap on homestead } \\
\text { exemption }\end{array}$ & $($ see text) & $\begin{array}{c}-0.0014 \\
(0.00053)\end{array}$ & 0.46 \\
\hline $\begin{array}{l}\text { Lagged bankruptcy } \\
\text { rate }\end{array}$ & $\begin{array}{l}+1 \text { standard deviation } \\
\quad=0.0054\end{array}$ & $\begin{array}{c}0.094 \\
(0.047)\end{array}$ & 31 \\
\hline $\begin{array}{l}\text { Last year's income } \\
\quad \text { (increase) }\end{array}$ & $+\$ 10,000$ & $\begin{array}{r}-0.042 \\
(0.012)\end{array}$ & -14 \\
\hline $\begin{array}{l}\text { Last year's income } \\
\text { (decrease) }\end{array}$ & $-\$ 10,000$ & $\begin{array}{c}0.086 \\
(0.028)\end{array}$ & 28.5 \\
\hline Years of education & +1 year & $\begin{array}{r}-0.024 \\
(0.010)\end{array}$ & -8.0 \\
\hline Age & +10 years & $\begin{array}{r}-0.080 \\
(0.018)\end{array}$ & -26.5 \\
\hline $\begin{array}{c}\text { Regression III } \\
\text { Divorce }\end{array}$ & From 0 to 1 & $\begin{array}{c}0.261 \\
(0.200)\end{array}$ & 86.5 \\
\hline
\end{tabular}

Notes: We compute each household's estimated probability of bankruptcy under the hypothesized change, holding all other household characteristics fixed. The marginal effect is the change in the probability of bankruptcy for that household. We average these marginal effects over all households, using the PSID weights, to get the results reported in the middle column. The rightmost column converts these marginal effects into a percentage change in the filing rate by dividing by the average probability of bankruptcy for the sample, which is 0.3017 percent. Figures in parentheses are bootstrapped standard errors, computed using 1,000 repetitions of the sample.

\section{Interpretation}

Table 5 gives predicted changes in the probability of filing for bankruptcy that result from given hypothetical changes in the values of selected variables, using regression I.

Suppose first that the financial benefit of bankruptcy increased by $\$ 1,000$ for all households. Then the average household's probability of filing for bankruptcy is predicted to rise by 0.021 percentage points. Since the average probability of filing in our sample is 0.3017 percent, the model predicts that the number of bankruptcy filings would increase by 7 percent per year. Based on 1.3 million bankruptcy filings per year in the United States (the figure for 1999), this implies that about 90,000 additional bankruptcy filings would occur per year.

In 1997, the National Bankruptcy Review Commission proposed the adoption of a uniform national bankruptcy exemption for personal property of $\$ 20,000$ for homeowners and $\$ 35,000$ for renters, with both exemptions doubled for married couples who file for bank- ruptcy. Under the proposal, states would still have the right to adopt their own homestead exemptions, but they could not be less than $\$ 20,000$ or greater than $\$ 100,000$. Suppose these proposals went into effect and suppose all states adopted homestead exemptions of $\$ 60,000$ - the midpoint of the allowed range. For each household in our sample, we calculate the resulting change in the financial benefit of filing for bankruptcy and use these figures to calculate the change in each household's probability of filing. (Note that many households' financial benefit from bankruptcy is unaffected by a change in the exemption level, since they have few nonexempt assets.) Because more households benefit from the higher homestead or personal property exemptions under the reform than are harmed by the loss of homestead exemptions exceeding $\$ 100,000$, the model predicts that the average probability of filing for bankruptcy would rise by 0.048 percentage points. This increase is highly significant, with a bootstrapped standard error of 0.011 . It translates into a 15.8-percent increase in the number 
of bankruptcy filings, or 205,000 additional bankruptcy filings each year.

The bankruptcy reform bill passed by the U.S. Senate in the spring of 2000 (S. 945, "Consumer Bankruptcy Reform Act of 1999”) proposed a more modest change: homestead exemptions would be capped at $\$ 100,000$. If we assume that this provision went into effect but all other aspects of bankruptcy law remained the same, then the model predicts that bankruptcy filings would fall by 0.0014 percentage points or by less than 0.5 percent. As a result, there would be about 6,000 fewer filings per year. This reform has such a modest effect because only 7 percent of households live in states with unlimited homestead exemptions and few of these households have dischargeable debt in excess of $\$ 100,000$.

Now turn to the effect of an increase in aggregate bankruptcy filings in household $i$ 's district. Suppose a single district in a single year experienced an increase in its bankruptcy filing rate equal to one standard deviation of the average district filing rate, which is 0.0054 . Then regression I predicts that the average probability of bankruptcy for households that live in that district would rise by 0.094 percentage points in the following year, implying that the number of bankruptcy filings in the district would increase by 31 percent. These results are consistent with local trends occurring in which increases in a district's bankruptcy filing rate cause attitudes toward bankruptcy to become more favorable and therefore individual households' probabilities of filing rise.

Now suppose average household income rises or falls by $\$ 10,000$ and consider the effect on bankruptcy filings one year later. The model predicts that an increase in income would lower the bankruptcy filing rate the following year by 0.042 percentage points, or 14 percent; while a decrease in income would raise the bankruptcy filing rate the following year by 0.086 percentage points, or 28 percent. The fall in income has a larger absolute effect on bankruptcy filings in the following year because it is more likely to affect both the income variable and the reduction in income variable. An additional year of education for household heads results in a predicted decline of 8 percent in the probability of bankruptcy, all else equal. If household heads were ten years older, their probability of bankruptcy would fall by 26 percent. Finally, using the results of regression III, when divorce occurs, household heads' probability of filing for bankruptcy is predicted to rise by 86 percent in the following year. Thus divorce has a large effect on bankruptcy filings, even controlling for financial benefit.

\section{Conclusions}

In this paper, we estimate a model of the household bankruptcy filing decision, using new data from the PSID on bankruptcy filings. We test whether households are more likely to file for bankruptcy when their financial benefit from filing-equal to the value of debt discharged in bankruptcy minus the value of nonexempt assets that households would have to give up in bankruptcy-rises. We find that an increase of $\$ 1,000$ in households' financial benefit from bankruptcy is associated with an increase of 0.021 percentage points-or 7 percent-in the probability of bankruptcy, and the relationship is statistically significant. However when we separate financial benefit into debts that would be discharged in bankruptcy versus nonexempt assets that must be given up in bankruptcy, we find that discharge of debt is the dominant consideration in households' decisions to file. We also assess the impact of two proposed changes in bankruptcy exemptions. We find that if the 1997 National Bankruptcy Review Commission's proposals were adopted, there would be 205,000 additional bankruptcy filings each year. In contrast, if the $\$ 100,000$ cap on homestead exemptions recently passed by the U.S. Senate were adopted, there would be only a negligible effect on the number of bankruptcy filings. We find little support for the alternate hypothesis that households file for bankruptcy when adverse events occur. Even after controlling for state and time fixed effects, households are more likely to file for bankruptcy if they live in districts which have higher aggregate bankruptcy filing rates, which suggests that local trends in bankruptcy filings are an important determinant of whether households file.

An important limitation of our study is that it is based on a relatively small number of bankruptcy filings, while alternate household data sets that include information on bankruptcy filings are not available. This lack of data has meant that, although Congress has hotly 
debated bankruptcy reform legislation each of the past several years, economists have been handicapped in their ability to provide good policy advice. Hopefully, better information will be available in the future to study this important issue.

\section{REFERENCES}

Ashenfelter, Orley. "Determining Participation in Income-Tested Social Programs." Journal of the American Statistical Association, September 1983, 78(383), pp. 517-25.

Barron, John M. and Staten, Michael E. "Personal Bankruptcy: A Report on Petitioners' Ability-to-Pay." Discussion paper, Credit Research Center, Georgetown University, 1998.

Braucher, Jean. "Lawyers and Consumer Bankruptcy: One Code, Many Cultures." American Bankruptcy Law Journal, Fall 1993, 67, pp. 501-83.

Buckley, Frank H. "The American Fresh Start." Southern California Interdisciplinary Law Journal, Fall 1994, 4, pp. 67-97.

Buckley, Frank H. and Brinig, Margaret F. "The Bankruptcy Puzzle." Journal of Legal Studies, January 1998, 27(1), pp. 187-207.

Chamberlain, Gary. "Analysis of Covariance with Qualitative Data." Review of Economic Studies, January 1980, 47(1), pp. 225-38.

Domowitz, Ian and Sartain, Robert L. "Determinants of the Consumer Bankruptcy Decision." Journal of Finance, February 1999, 54(1), pp. 403-20.

Dye, Ronald A. "An Economic Analysis of Bankruptcy Statutes." Economic Inquiry, July 1986, 24(3), pp. 417-28.

Fay, Scott; Hurst, Erik and White, Michelle J. "The Bankruptcy Decision: The Roles of Financial Benefit and Stigma." Working paper, University of Michigan, 1998.

Greene, William. Econometric analysis, 2 nd Ed. New York: Prentice-Hall, 1993.

Gropp, Reint; Scholz, John Karl and White, Michelle J. "Personal Bankruptcy and Credit Supply and Demand." Quarterly Journal of Economics, February 1997, 112(1), pp. 21751.

Gross, David B. and Souleles, Nicholas S. "An Empirical Analysis of Personal Bankruptcy and Delinquency." Review of Financial Studies, Spring 2002, 15(1), pp. 319-47.
Gross, Karen. "Preserving a Fresh Start for the Individual Debtor: The Case of Narrow Construction of the Consumer Credit Amendments." University of Pennsylvania Law Review, December 1986, 135, pp. 59152.

Hausman, J. A.; Abrevaya, Jason and ScottMorton, F. M. "Misclassification of a Dependent Variable in a Discrete-Response Setting." Journal of Econometrics, December 1998, 87(2), pp. 239-69.

Hurst, Erik; Luoh, Ming-Ching and Stafford, Frank P. "The Wealth Dynamics of American Families, 1984-94." Brookings Papers on Economic Activity, 1998, (1), pp. 267-329.

Moffitt, Robert. "Participation in the AFDC Program and the Stigma of Welfare Receipt: Estimation of a Choice-Theoretic Model." Southern Economic Journal, January 1981, 47(3), pp. 753-62.

National Bankruptcy Review Commission. Bankruptcy: The next twenty years. Washington, DC: U.S. Government Printing Office, 1997.

Rea, Samuel A., Jr. "Arm-breaking, Consumer Credit and Personal Bankruptcy." Economic Inquiry, April 1984, 22(2), pp. 188-208.

Staten, Michael. "The Impact of Post-Bankruptcy Credit on the Number of Personal Bankruptcies." Credit Research Center, Krannert Graduate School of Management Working Paper No. 58, Purdue University, 1993.

Sullivan, Teresa A.; Warren, Elizabeth and Westbrook, Jay Lawrence. As we forgive our debtors: Bankruptcy and consumer credit in America. New York: Oxford University Press, 1989.

U.S. Department of Commerce. Statistical $a b$ stract of the United States. Washington, DC: U.S. Government Printing Office, 1997.

Visa U.S.A., Inc. Consumer bankruptcy: Annual bankruptcy debtor survey. 1997. [Online: 〈www.abiworld.org/stats/visa〉.]

Washington Post. "Bad Ideas on Bankruptcy." 18 February 2000, p. A22.

Wells, Wayne R.; Kurtz, Janell M. and Calhoun, Robert J. "The Implementation of Bankruptcy Code Section 707(b): The Law and the Reality." Cleveland State Law Review, 1991, 39, pp. 15-48.

White, Michelle J. "Personal Bankruptcy Under the 1978 Bankruptcy Code: An Economic Analysis." Indiana Law Journal, Winter 1987, 63(1), pp. 1-53. 
. "Why Don't More Households File for Bankruptcy?" Journal of Law, Economics, and Organization, October 1998a, 14(2), pp. 205-31. . "Why It Pays to File for Bankruptcy:
A Critical Look at the Incentives under U.S. Personal Bankruptcy Law and a Proposal for Change." University of Chicago Law Review, Summer 1998b, 65(3), pp. 685-732. 